\title{
The macroinvertebrate fauna of the Młynne stream (Polish Carpathians) in the aspect of the bed load transport and water quality
}

\author{
PAWEŁ OGLĘCKI ${ }^{1}$, ARTUR RADECKI-PAWLIK ${ }^{2}$ \\ ${ }^{1}$ Department of Environmental Improvement, Engineering, Warsaw University of Life Sciences - SGGW \\ ${ }^{2}$ Department of Water Engineering and Geotechnics, University of Agriculture in Krakow
}

\begin{abstract}
The macroinvertebrate fauna of the Mtynne stream (Polish Carpathians) in the aspect of the bed load transport and water quality. The qualitative composition of the bottom sediments and the bed load and suspended load transport along the mountain stream were presented. The studies were carried on the Młynne stream in Gorce (Polish Carpathians). The streams flows partially in the natural river-bed and partially in the regulated with rapids. The stream bed load is accumulated in the reservoir up to the check dam and is qualitatively different from the load deposited at the bars. The taxonomic richness of the Młynne stream is a little bigger compared with the other investigated mountain and sub-mountain streams, but lesser compared with bigger rivers. The number of taxa on the natural reaches is more than double than on the regulated ones, with more taxa of high environmental demands and high values of the BMWP-PL index. The paper brings up the question of the environmental friendly technical solutions in different human activities in the sub-mountain and mountain river valleys, advantageous for humans and the river biological diversity (or resistance for negative environmental factors) as well.
\end{abstract}

Key words: mountain stream, bed load transport, macroinvertebrates, habitats differentiation, Carpathians, river

\section{INTRODUCTION}

The bed load of mountain streams in the Polish Carpathians is the subject of many scientific studies (Gładki et al. 1981, Bartnik 1992, Radecki-Pawlik 2000, Ratomski 2000). Because of many reasons the bed load movement is stemmed with transverse barriers called the check dams (Wołoszyn et al. 1994, Ratomski 2000). In the catchment areas, where the slopes are still endangered by erosion, the suspended load (as well as washed load) seriously helps in bed load supply (Bartnik and Madeyski 1992, Banasik 1994).

It is very important in the light of hydromorphological degradation of mountain and sub-mountain streams, being recognized as an important stressor affecting the composition of macroinvertebrate communities. The recent study on Czarny Dunajec in the Polish Carpathians identified a dependence of the taxonomic richness of invertebrate communities on the physical habitat heterogeneity. It is usually connected with the problem of river regulation - the regulated reaches host more and much more differentiated taxa than the regulated ones because of the abundance (presence/absence) of typical, repeatable habitats (Wyżga et al. 2012, 2013a, b, 2014). The determination of the state of macroinvertebrate 
fauna in the stream, eventuating from the bed load transport and water quality, was the aim of the study.

\section{STUDY AREA}

The Młynne catchment is the part of Western Carpathian Province, Outer Western Carpathians Subprovince, Outer Western Beskids Macroregion and Gorce Mezoregion. The Młynne stream is left tributary of the Ochotnica stream (right Dunajec river tributary). On the lower reach (from the check dam to the mouth) the terrain elevation gradient is equal to $90 \mathrm{~m}$ and the average slope is equal to $3.6 \%$. The upper reach average slope is equal to $10.2 \%$ and the stream valley development $(V)$ - figured out according to Horton (1945) - is equal to 0.364 . The orographic index $(\lambda)$ according to Kajetanowicz, equal to 777.48 , classifies the Młynne stream as high-mountain watercourse and Łochtin stability parameter $(f)$, equal to 0.913 , defines the Młynne stream riverbed as vulnerable to erosion (Wołoszyn et al. 1994).

The whole Młynne catchment area lays in the Gorce mountains, built in major part from Magura Set sedimentary rocks. The rocks of this set cover the largest area in Outer Western Flysch Carpathians and build the Żywiecki Beskid Mountains, a larger part of Medium Beskids, Insular Beskids, Sadecki Beskids and the part of Low Beskids. The Magura Set sedimentary rocks are classed as so-called flysch, consisted of alternating layers of sandstones, mud shales, pudding stones, mudstones and siltstones. The flysch is often accompanied by the carbonate rocks, such as limestones, marls and dolomites, also found in the Gorce mountains. The
Magura Set was creating itself for relatively long time - about 63 million years. Its oldest link - motley shales - formed a deposits in turon (upper Cretaceous) and the youngest one - the Magura layers - in Oligocene (lower Tertiary). All the hilltops in Gorce and other mentioned ridges are built with Magura sandstones, which formed the deposits in the sea in upper Eocene (lower Tertiary). The Magura sandstones thickness reaches about $200 \mathrm{~m}$. It is consisted of thick shoals with thick or middle-sized grains, in Gorce most often greyish with muscovite (Matuszczyk 1999). In the Młynne stream valley the ensembles of thickand thin-shoaled sandstones, shifted by greyish shales, are being exposed. In the Młynne stream riverbed, especially in its upper reach, abundant rock verges occur. The mica sandstones and shales of Magura layer dominate in that part. In the middle catchment area there are basically Tertiary (paleogene) shales and sub-Magura layer sandstones with the lens of Quaternary slide colluviums. In the mouth reach the Cretaceous sandstones and the shales of Ropa layer (Kulka et al. 1991). In the Młynne stream valley, in lower part of the catchment area, sparse alluvial settlements are also present.

On the upper reach of the Młynne stream catchment area its significant part is covered by the Asperulo-Fagetum beech forest with firs and spruces. On the upper reach, down from the dam, the spruce forests dominate. It was (Szwalec et el. 2007) that approximately $50.6 \%$ of the arable lands is exposed to sheet erosion (about 21.2\% - to intensive one, $28.3 \%$ - to strong one, $1.1 \%$ - to very strong one). Amongst arable lands the biggest area (about 50\%) is covered by 
mountain oat-pasture soils complex and about $33 \%$ - by mountain oat-potato soils complex.

The climate of the study area is characterised by short, rainy summer but long, sunny autumn. The warm winds precipitate the snow melting. The annual rainfall in the Młynne valley is about $720 \mathrm{~mm}$. The chemical composition of the Młynne stream is similar to others small watercourses in Carpathian mountains of similar catchment area exploitation. The water quality is good, but in the cross-sections 1 and 2 during all study period the significant decline was noticed, what was linked to the hydrological conditions changes and riverbed insolation (Radecki-Pawlik et al. 2002).

\section{METHODS}

The stream reach from $0.0 \mathrm{~km}$ (Młynne mouth to the Ochotnica stream - $495 \mathrm{~m}$ a.s.l.) to $7+500 \mathrm{~km}$ (985 m a.s.l.) was being investigated. The Młynne stream was divided into for study reaches, the following cross-sections were set down: cross-section 1 in $0+150 \mathrm{~km}(498 \mathrm{~m}$ a.s.l.) - "Rapids", cross-sections 2, 3 and 4 in $2+800 \mathrm{~km} \mathrm{(585} \mathrm{m}$ a.s.l., the neighbourhood of the reservoir just up the check dam - "Reservoir"; sample 2 was taken from fine-grained, firm sediment, deposited just down the mouth of the check dam notch; sample 3 - from the sediments near the Młynne old riverbed in down-dam reservoir; sample 4 - from the reservoir bank in the inlet), cross-section 5 in $3+600 \mathrm{~km}(610 \mathrm{~m}$ a.s.l., in the built-up area, on the natural reach of the riverbed - "School") and cross-section 6 in $4+300 \mathrm{~km}(655 \mathrm{~m}$ a.s.l., natural stream - "Kotelniki"). T-year flood values $(Q)$ for the Młynne stream estuary were calculated using Punzet method (Punzet 1981, Radecki-Pawlik 1995), and the results are presented in Table 1.

The bed load transport was calculated using Meyer-Peter and Müller formula which is advised to be applied in Polish Carpathians. All calculations run used that formula included all fractions of the bed load material (Michalik 1990, Bartnik 1992):

$$
q_{i}=\left[\frac{\rho_{w} g h I-f_{i} g \Delta \rho d_{i}}{0.25 \rho_{w}^{\frac{1}{3}}}\right]^{1.5} p_{i} b
$$

where :

$q_{i}$ - bed load transport value $\left(\mathrm{N} \cdot \mathrm{s}^{-1}\right)$,

$\rho_{w}, \rho_{r}-$ water and bed load density

$\left(\mathrm{kg} \cdot \mathrm{m}^{-3}\right)$,

$g$ - weight of bed material,

$h$ - water depth (m),

$I$ - slope (-),

$f_{i}$ - shear stresses for particular sediment fractions (-),

$\Delta \rho=\rho_{r}-\rho_{w}$,

$d_{i}-$ fractional diameter,

$p_{i}-$ percentage of the sediment fractions (\%),

$b$ - active river width (m).

TABLE 1 . T-year flood values $(Q)$ for the Młynne stream estuary

\begin{tabular}{|l|c|c|c|c|c|c|c|}
\hline$p(\%)$ & 0.01 & 0.10 & 0.20 & 0.50 & 1.00 & 2.00 & 3.00 \\
\hline$Q\left(\mathrm{~m}^{3} \cdot \mathrm{s}^{-1}\right)$ & 130.1 & 98.2 & 88.3 & 75.0 & 64.8 & 54.4 & 48.2 \\
\hline$p(\%)$ & 5 & 10 & 20 & 25 & 30 & 40 & 50 \\
\hline$Q\left(\mathrm{~m}^{3} \cdot \mathrm{s}^{-1}\right)$ & 40.4 & 29.7 & 18.9 & 15.6 & 13.0 & 9.3 & 7.7 \\
\hline
\end{tabular}


Field survey and slopes measurements were done with TOPCON AT-G7 survey professional level device. For sediment analysis the grain size curves were developed on the base of classical sieving survey (Church et al. 1987).

The bedload transport value was calculated using the SandCalc 1 software (Wallingford University 1996).

The USLE method (Banasik 1994) was used to calculate of the suspended load transport in the catchment. In 1940 Zingg publicised the soil loses equation, taking into account the downslope and the length of the hillside. Currently, the Wischmeier and Smith Universal Soil Loses Equation (USLE) and its modifications are being used (Tarnawski 1996). USLE is the modification of Musgrave equation (Banasik and Górski 1992, Banasik 1994):

$$
E=R K S C P
$$

where:

$E$ - eroded mass of soil from the investigated area along the year $\left(\mathrm{t} \cdot \mathrm{ha}^{-1}\right.$. - year $^{-1}$ ),

$R$ - precipitation coefficient (Je $\cdot$ year $^{-1}$ ), where Je is errosion unit $\left(\mathrm{MJ} \cdot \mathrm{ha}^{-1}\right.$. $\left.\cdot \mathrm{cm}^{-1} \cdot \mathrm{h}^{-1}\right)$,

$K-$ erosion coefficient $\left(\mathrm{t} \cdot \mathrm{ha}^{-1} \cdot \mathrm{Je}^{-1}\right)$,

$L$ - slope-lenght coeficient (-),

$S$ - slope coefficient (-),

$C$-slope management coefficient (-),

$P$ - errosion management coefficient (-).

Washlod in the river is a part of the erroded mass from the catchment and it might be calculated using DR-USLE (Banasik i Górski 1992) formula:

$$
Y=D R E
$$

where:

$Y$ - mass of washload in the outlet point of the catchment along the year $\left(\mathrm{t} \cdot \mathrm{year}^{-1}\right)$,

$D R$ - washload coefficient (-),

$E-$ as in the USLE method.

Detailed discussions on the individual parameters were provided by Banasik (1994) and Banasik and Górski (1992).

Water samples for chemical composition analysis were taken four times (7.04.2013, $15.06 .2013,2.08 .2013,19.10 .2013)$ in the cross-sections 1, 2, 5 and 6 (the cross-section 2 was considered as the most representative for water physic-chemical composition tests in the down-dam reservoir neighbourhood). The chemical composition test were carried out according to standard methods (Hermanowicz et al. 1999). The electrolytical conductivity was measured with Elmetron CC-317 micro-computer conductometer, and $\mathrm{pH}-$ with Hydromet ERH-11 electrode. Most measurements (total hardness, dissolved oxygen, ammonia, nitrates, nitrites, phosphates) were done in the field with the help of Slandi LF-204 photometer. The chemical oxygen demand measurements were made in the laboratory.

Benthic invertebrate samples were collected on the 21 of July and on the 2 of November 2013. The sampling focused on determining the composition of the assemblages only. In each cross-section, samples were collected at three sites representing principal, visually identified physical habitat conditions (such as water depth, bottom substrate and flow velocity). At each site, macroinvertebrates were collected from about $0.1 \mathrm{~m}^{2}$ of the bed. Sampling was done with triangular dip net, Ekman grab, mosquito dipper and tweezers - in dependence to 
habitat conditions in particular sites, in order to collect as many taxa as possible. The macroinvertebrates were identified in the laboratory, partly from non-preserved material during 2-3 days after the sampling and partly from the samples preserved with $70 \%$ ethanol. All the specimen were identified to the lowest unquestionably identifiable taxonomic level, with the help of specialist guides (McCafferty 1998, Kołodziejczyk and Koperski 2000). The taxonomic differences between peculiar cross-sections were analysed statistically using the Kruskal-Wallis test.

\section{RESULTS AND DISCUSSION}

The results of measurements and calculations referring to respectively the bedload transport and suspended load transport are presented in Tables 2-5.

For the parameters put in Table 5, the mass of washload $(Y)$ in the outlet point of the catchment is equal to $72.64 \mathrm{t} \cdot \mathrm{year}^{-1}$.

The bed load transport in all the cross-section of the Młynne stream is small. Its range is equal to $0.009-0.016 \mathrm{~N} \cdot \mathrm{s}^{-1} \cdot \mathrm{m}^{-1}$ in the case of waterline $\left(Q_{b}\right)$, while in other Polish Carpathians streams, investigated by Michalik (1990), the measured transport equivalent to $Q_{b}$, is larger and equal, respectively, in the Wisłoka stream - 0.018-0.146 N.s. $\mathrm{lm}^{-1}$, in the Raba stream $-0.06-0.70 \mathrm{~N} \cdot \mathrm{s}^{-1} \cdot \mathrm{lm}^{-1}$. and in the Dunajec river $-0.31-0.34 \mathrm{~N} \cdot \mathrm{s}^{-1} \cdot \mathrm{lm}^{-1}$. The North American streams of the flow regime similar as in the Młynne, such as East Fork in Wyoming, Snake River in Idaho and Mountain Creek in South California, are characterised by higher transport values, respectively $-0.1-0.7$, $0.1-1.0$ and $0.005-0.100 \quad \mathrm{~N} \cdot \mathrm{s}^{-1} \cdot \mathrm{m}^{-1}$ (Gomez and Church 1988). The mass of washload $(Y)$ shed from the Młynne catchment is equal to 72,64 t.year ${ }^{-1}$. For the comparison, in the case of the Dłubnia stream the $Y$ values, measured for many years, vary from 680 to 69,997 t.year ${ }^{-1}$ (Bednarczyk 1994). According to Banasik and Madeyski (1990), Bartnik and Górski (1992), the values of the sling load transport for the Poniczanka stream, the Mszanka stream, the Lubieńka stream, the Bystra stream and the Skawica stream are equal, respectively, 1,917, 4,258, 3,254, 1,671 and 1,544 t.year- ${ }^{-1}$. Since, despite the high value of Łochtin parameter, the sling load transport in the Młynne stream is relatively small.

The water temperature in the Młynne stream was changing during the year in

TABLE 2. Bed load transport in cross-section 6 "Kotelniki"

\begin{tabular}{|c|c|c|c|}
\hline $\begin{array}{c}\text { Water depth } \\
(\mathrm{m})\end{array}$ & $\begin{array}{c}\text { Terrain altitude } \\
(\mathrm{m})\end{array}$ & $\begin{array}{c}\text { Velocity of water } \\
\left(\mathrm{m} \cdot \mathrm{s}^{-1}\right)\end{array}$ & $\begin{array}{c}\text { Unit transport, } \\
\left(\mathrm{N} \cdot \mathrm{s}^{-1} \cdot 1 \mathrm{~m}^{-1}\right)\end{array}$ \\
\hline 0.1 & 655.1 & 0.619 & no transport \\
\hline 0.3 & 655.3 & 1.374 & no transport \\
\hline 0.5 & 655.5 & 2.036 & 0.000726 \\
\hline 0.7 & 655.7 & 2.547 & 0.002628 \\
\hline 0.9 & 655.9 & 3.021 & 0.005340 \\
\hline 1.2 & 656.2 & 3.617 & 0.009980 \\
\hline
\end{tabular}

Total bed load $(q)$ in cross-section 6 is $0.018674 \mathrm{~N} \cdot \mathrm{s}^{-1} \cdot \mathrm{lm}^{-1}$. 
TABLE 3. Bed load transport in cross-section 5 "School"

\begin{tabular}{|c|c|c|c|}
\hline $\begin{array}{c}\text { Water depth } \\
(\mathrm{m})\end{array}$ & $\begin{array}{c}\text { Terrain altitude } \\
(\mathrm{m})\end{array}$ & $\begin{array}{c}\text { Velocity of water } \\
\left(\mathrm{m}^{-1}\right)\end{array}$ & $\begin{array}{c}\text { Unit transport, } q_{50} \\
\left(\mathrm{~N} \cdot \mathrm{s}^{-1} \cdot \mathrm{m}^{-1}\right)\end{array}$ \\
\hline 0.1 & 610.1 & 0.964 & no transport \\
\hline 0.3 & 610.3 & 1.902 & no transport \\
\hline 0.5 & 610.5 & 2.238 & 0.002033 \\
\hline 0.7 & 610.7 & 2.841 & 0.004725 \\
\hline 0.9 & 610.9 & 3.395 & 0.015800 \\
\hline 1.2 & 611.2 & 4.088 & 0.016250 \\
\hline
\end{tabular}

Total bed load $(q)$ in cross-section 5 is $0.038808 \mathrm{~N} \cdot \mathrm{s}^{-1} \cdot \mathrm{lm}^{-1}$.

TABLE 4. Bed load transport in cross-section 2 "Reservoir"

\begin{tabular}{|c|c|c|c|}
\hline $\begin{array}{c}\text { Water depth } \\
(\mathrm{m})\end{array}$ & $\begin{array}{c}\text { Terrain altitude } \\
(\mathrm{m})\end{array}$ & $\begin{array}{c}\text { Velocity of water } \\
\left(\mathrm{m} \cdot \mathrm{s}^{-1}\right)\end{array}$ & $\begin{array}{c}\text { Unit transport, } \\
\left(\mathrm{N} \cdot \mathrm{s}^{-1} \cdot \mathrm{lm}^{-1}\right)\end{array}$ \\
\hline 0.1 & 585.1 & 0.643 & no transport \\
\hline 0.3 & 585.3 & 1.338 & no transport \\
\hline 0.5 & 585.5 & 1.880 & 0.0002631 \\
\hline 0.7 & 585.7 & 2.303 & 0.0013530 \\
\hline 0.9 & 585.9 & 2.028 & 0.0002289 \\
\hline 1.2 & 586.2 & 2.878 & 0.003404 \\
\hline
\end{tabular}

Total bed load $(q)$ in cross-section 5 is $0.005249 \mathrm{~N} \cdot \mathrm{s}^{-1} \cdot \mathrm{lm}^{-1}$.

TABLE 5. Suspended load transport in cross-section 1 "Rapids"

\begin{tabular}{|c|c|c|}
\hline Coefficient & Value & SI units \\
\hline$R$ & 111.8 & $\mathrm{Je}^{-} \mathrm{year}^{-1}$ \\
\hline$K$ & 0.579 & $\mathrm{t} \cdot \mathrm{ha}^{-1} \cdot \mathrm{Je}^{-1}$ \\
\hline$L S$ & 0.133 & - \\
\hline$C$ & 0.057 & - \\
\hline$P$ & 0.584 & - \\
\hline$D R$, according to Roehl & 0.216 & - \\
\hline
\end{tabular}

the range $4.8-17.0^{\circ} \mathrm{C}$, reaching the highest values in the summer, in the cross-sections 1 and 2. The water reaction was shifted to the alkaline (the $\mathrm{pH}$ values in summer were higher than 8.0 ), what was linked to abundant peryphiton presence on the firm, stony bottom. The similar tendency was recorded during the vegetation period in many streams in Małe Pieniny (Small Pieniny) area and in the Raba tributaries (Bombówna 1969, 1982). The water hardness varied from 80-125 $\mathrm{mg} \mathrm{CaCO}_{3} \cdot \mathrm{dm}^{-3}$, what allows to class the Młynne stream water as soft little hard one (Dojlido 1995, Hermanowicz et al. 1999) The electric conductivity was relatively low, the increasing in the values during the summer season in cross-sections 1 and 2 was linked to the increasing in wastes amounts in low flows (Bombówna 1982). Chemical oxygen demand, being the indicator of organic compounds' contents in water, varied from 2.8 to $4.9 \mathrm{mg} \mathrm{O}_{2} \cdot \mathrm{dm}^{-3}$. Except for the spring, the chemical oxygen demand level was levelised, what denotes the allochtonic origin of organic compounds, as well as their intensive surface runoff from the catchment area (Bombówna 1960). The contents of dissolved 
oxygen was changed in dependence to the season and investigated cross-section. The highest values $(10.41-8.10 \mathrm{mg}$ $\mathrm{O}_{2} \cdot \mathrm{dm}^{-3}$ ) were noted in all the cross-sections in April, what is quite normal with low temperature and low level of epiphyte algae growth, and the lowest ones in the summer in cross-sections 1 and 2 (4.85-5.30 $\mathrm{mg} \mathrm{O}_{2} \cdot \mathrm{dm}^{-3}$, what subtents III and II water purity classes according to Polish standards - Rozporządzenie Ministra Ochrony Środowiska 1991). Water in the Młynne stream is poor in ammonia and nitrites, but contents higher than normative amount of nitrates, mainly in the cross-sections 1 and 2 . In the spring a higher contents of nitrates were noted in cross-sections 5 and 6 , what is linked to supplies from the soil (with surface inflows). In the summer the mentioned values significantly declined, what was linked to nitrogen utilization by peryphiton. The similar situation was observed in low-polluted Raba tributaries - Mszanka, Kasinka, Krzczonówka and others (Bombówna 1969, Lipski and Michalczewski 1992).

The content of phosphates in the Młynne stream was also low, what is typical for such streams (Bombówna 1960, 1976), although in the cross-sections 1 and 2 the mentioned content was higher than in the cross-sections 5 and 6, what denotes the higher supply of that compounds and their lower utilization by algae (Bombówna 1976, 1982).

The invertebrate fauna in the Młynne stream is poorer compared with larger mountain and sub-mountain rivers, investigated by authors (Czarny Dunajec, Biała Tarnowska), but similar in the comparison with the Raba river tributaries of the similar size - Trzebunka and
Krzczonowka, and Raba itself as well (Tables 6, 7). The significant differences between the Młynne stream cross-sections are clearly noticeable - the 1,2,3 and 4 ("Rapids" and "Reservoir") host just a few taxa typical for mountain and sub-mountain streams (stoneflies, mayflies). On the contrary - the upper cross-sections 5 and 6 ("School" and "Kotelniki") are quite abundant, with the full spectrum of ecological types of macroinvertebrates. The Kruskal-Wallis test showed that the difference between the cross-sections 1-4 and 5-6 is statistically significant (Fig.) with P-value less than 0.05 (equal to 0.0125765 ). The cross-sections 5 and 6 represent the highest ecological status according to the BMWP-PL index and seem to be substantially valuable in strictly biological and ecological terms (Table 7). The basic reason is the habitat heterogeneity and the presence of many microhabitats - specific, unique structures, inhabited by the taxa of such particular environmental demands (parts of ecological niches). The lower reaches (1, 2, 3 and 4) are rather homogenous and do not ensure the microhabitats for a lot of species. In the consequence, the majority of taxa found in the cross-sections typical for mentioned reaches are the ones of wide tolerance for environmental factors (Tabanus sp., Hydropsyche sp.). The exceptions are rare - for example Capnidae in the cross-sections 1 and 2 or Ephemera in the cross-section 4. The similar pattern was noted in the other mountain rivers (Wyżga et al. 2013) and lowland rivers (e.g. Tolkamp 1980).

It is worth emphasizing the dilemma - the stream or river regulation, realised in the name of the flood control, at the 
TABLE 6. The total number of invertebrate taxa, the highest BMWP-PL values and the highest ecological class values for the Młynne stream and other investigated mountains and sub-mountain rivers

\begin{tabular}{|l|c|c|c|c|c|c|}
\hline \multirow{2}{*}{ Parameter } & \multicolumn{5}{|c|}{ River } \\
\cline { 2 - 7 } & Młynne & Trzebunka & Krzczonowka & Raba & $\begin{array}{c}\text { Czarny } \\
\text { Dunajec }\end{array}$ & $\begin{array}{c}\text { Biała } \\
\text { Tarnowska }\end{array}$ \\
\hline Total number of taxa & 24 & 28 & 28 & 27 & 37 & 43 \\
\hline $\begin{array}{l}\text { Highest numer of taxa in the } \\
\text { cross-section }\end{array}$ & 23 & 25 & 25 & 25 & 33 & 32 \\
\hline $\begin{array}{l}\text { Lowest number of taxa in the } \\
\text { cross-section }\end{array}$ & 8 & 14 & 12 & 5 & 15 & 9 \\
\hline $\begin{array}{l}\text { Highest BMWP-PL index } \\
\text { value for the cross-section }\end{array}$ & 122 & 109 & 137 & 101 & 167 & 209 \\
\hline $\begin{array}{l}\text { Lowest BMWP-PL index value } \\
\text { for the cross-section }\end{array}$ & 37 & 67 & 49 & 31 & 74 & 53 \\
\hline $\begin{array}{l}\text { Highest ecological value of the } \\
\text { cross-section }\end{array}$ & I & I & I & I & I & I \\
\hline $\begin{array}{l}\text { Lowest ecological value of the } \\
\text { cross-section }\end{array}$ & IV & III & III & IV & II & III \\
\hline
\end{tabular}

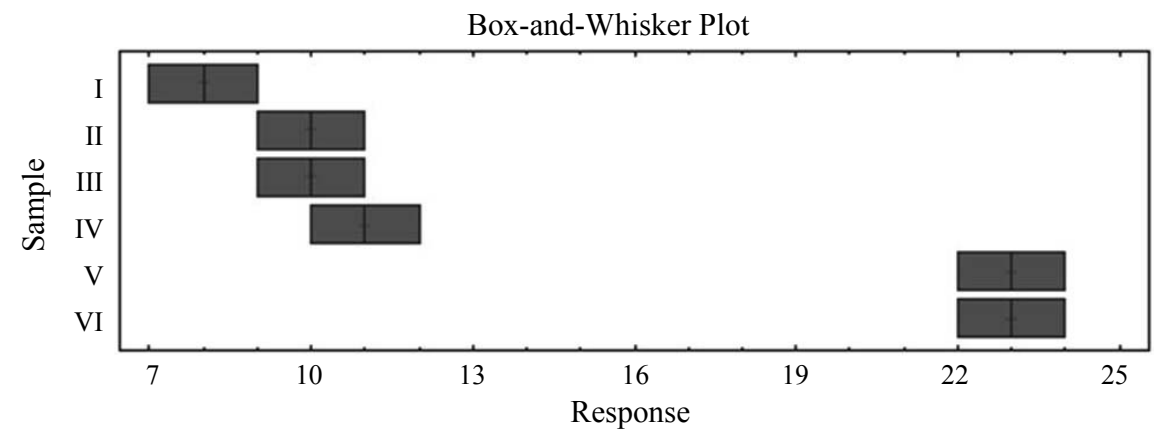

FIGURE. The graphic result of the Kruskal-Wallis test (the sample numbers represent the peculiar cross-sections)

same time reduces the biological diversity of the water body and make them more vulnerable for environmental disasters (high biological diversity is considered to be one of the most important factor protecting the eco-system against environmental stresses). It is very important to realize flood control activities in environmental-friendly way, with natural materials use and no-invasive techniques, if it is possible. This may be the step towards the compromise between the environmental and human needs. 


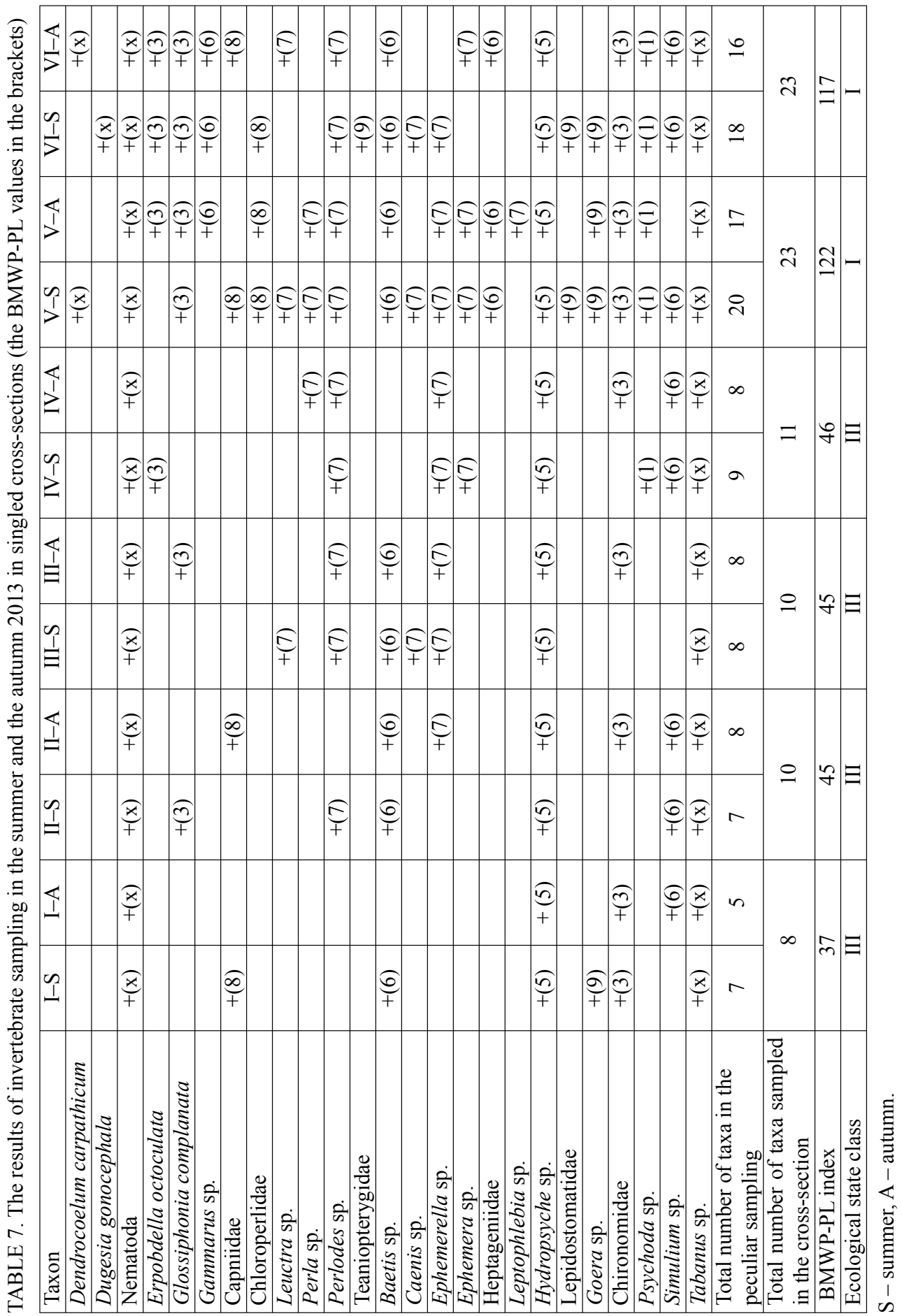




\section{CONCLUSIONS}

1. During the full-bed and up-bed floods the Młynne stream transports - in the comparison with other mountain streams - less bed load (from 0.009 to $0.0160 \mathrm{~N} \cdot \mathrm{s}^{-1} \cdot \mathrm{m}^{-1}$ ).

2. The mass of washload $(Y)$ from the Młynne stream catchment area is significantly lesser in the comparison with the mass of suspended load in others Carpathian streams' catchments and should be considered as the little one.

3. The physic-chemical parameters of the Młynne stream water is similar to the ones of other Carpathian streams with analogical kind of exploitation.

4. In the low cross-sections during all the study period the evident decreasing in water quality was observed, what was unquestionably linked to the hydrological conditions changes (especially flow conditions) and riverbed insolation.

5. The invertebrate fauna of the Młynne stream is abundant and differentiated compared with similar mountain streams.

6 . The natural reaches host more than double number of taxa than the regulated ones.

7. The ecological value and capability to minimize the negative environmental effects are much larger on the natural reaches.

8. There is a necessity to bring on the environmental friendly solutions in the rivers regulations to improve their ecological values.

\section{REFERENCES}

BANASIK K. 1994: Model sedymentgramu wezbrania opadowego $\mathrm{w}$ małej zlewni rolniczej
[Conceptual model of sedimentgraph from flood events in a small agricultural watershed]. Rozprawy Naukowe i Monografie SGGW, Warszawa (Engl. summ.).

BANASIK K., GÓRSKI D. 1992: Wykorzystanie uniwersalnego równania strat glebowych USLE do oceny ilości rumowiska unoszonego odpływającego z małych zlewni [Using of the universal equation for soil loses UCLE for the estimation of bed load run off in small catchments]. Gosp. Wod. 3, 12-14 (Engl. summ.).

BANASIK K., MADEYSKI M. 1990: Próba wykorzystania zmodyfikowanego równania strat glebowych do oceny ilości rumowiska unoszonego w falach wezbraniowych małych zlewni karpackich [An attempt to use a modified universal soil loss equation for evaluating suspended load in the flood waves in small Carpathian watersheds]. Zesz. Probl. Post. Nauk Rol. F, 82 (3), 8-15 (Engl. summ.).

BARTNIK W. 1992: Hydraulika potoków i rzek górskich z dnem ruchomym. Początek ruchu rumowiska [The mountains movable bottom streams and rivers hydraulics. The beginning of the bedload transport]. Zesz. Nauk. AR w Krakowie, Rozpr. Hab. 171 (Engl. summ.).

BARTNIK W., MADEYSKI M. 1992: Denudacja w małych zlewniach górskich jako jeden z czynników określania natężenia erozji [Denudation in the stream basins as the factor estimating of rain wash]. Zesz. Nauk AR w Krakowie, Sesja Naukowa 35, part I, 271, 257-265 (Engl. summ.).

BEDNARCZYK T. 1994: Określenie ilości unoszonego rumowiska $\mathrm{w}$ przekroju małego zbiornika wodnego w Zesławicach [The determination of silting degree of water reservoir AT Zesławice]. Zesz. Nauk. AR w Krakowie 15, Inżynieria Środowiska, 12-26.

BOMBÓWNA M. 1969: Hydrochemiczna charakterystyka rzeki Raby i jej dopływów. [Hydrochemical profile of the Raba River and its tributaries]. Acta Hydrobiol. 11 (4), 479-504.

BOMBÓWNA M. 1976: Rzeka Skawa-chemizm wody i eutrofizacja [The Skawa River - water chemistry and eutrophisation]. Acta Hydrobiol. 18 (4), 407-420 (Engl. summ.).

BOMBÓWNA M. 1982: Stream ecosystems in mountain grassland (West Carpathians). 3 . Chemical composition of water. Acta Hydrobiol. 24 (4), 321-335 (Engl. summ.). 
CHURCH M.A., MCLEAN J.F., WOLCOT J.F. 1987: River Bed Gravels: Sampling and Analysis. In: C.R. Throne et al. (Eds.). Sediment Transport in Gravel-bed Rivers. John Wiley and Sons, London, 43-87.

DOJLIDO J.R. 1995: Chemia wód powierzchniowych [Surface waters chemistry]. Wydawnictwo Ekonomia i Środowisko, Warszawa (in Polish).

GŁADKI H., MICHALIK A., BARTNIK W. 1981: Measurement of bed-load transport in mountain streams using radioactive tracers method. Proceedings of Workshop IAHR, Rapperswil, 420-451.

GOMEZ B., CHURCH M. 1988: A catalogue of equilibrium bedload transport data for coarse sand and gravel-bed channels. University of British Columbia, Vancouver.

HERMANOWICZ W., DOŻAŃSKA W., DOJLIDO J., KOZIOROWSKI B. 1999: Fizyczno-chemiczne badanie wody i ścieków [Physo-chemical surveys of water and savages]. Arkady, Warszawa (in Polish).

HORTON R.E. 1945: Erosional development of streams and their drainage basins; hydrophysical approach to quantitative morphology. Bulletin of the Geological Society of America 56, 275-370.

KOŁODZIEJCZYK A., KOPERSKI P. 2000: Bezkręgowce słodkowodne Polski [Freshwater invertebrates of Poland]. Wydawnictwo UW, Warszawa (in Polish).

KULKA A., RĄCZKOWSKI W., ŻYTKO K., PAUL Z. 1991: Szczegółowa mapa geologiczna Polski [The detailed geological map of Poland]. Wydawnictwa Geologiczne, PIG, Warszawa (in Polish).

LIPSKI C., MICHALCZEWSKI M. 1992: Zawartość niektórych składników chemicznych w wodzie potoku Lubieńka [The contents of some chemical compounds in the Lubienka Stream water]. Zesz. Nauk. AR Kraków 273, 145-157 (Engl. summ.).

MATUSZCZYK A. 1999: Gorce [The Gorce Mountains]. REWASZ, Warszawa (in Polish).

McCAFFERTY W.P. 1998: Aquatic Entomology. Jones and Bartlett Publishers, Sadbury, Massachusetts.

MICHALIK A. 1990: Badania intensywności transportu rumowiska wleczonego w rzekach karpackich [The investigations of the bedload transport intensity in Carpathains rivers]. Zesz.
Nauk. AR w Krakowie, Rozpr. Hab. 138 (Engl. summ.).

PUNZET J. 1981: Empiryczny system ocen charakterystycznych przepływów rzek i potoków w karpackiej części dorzecza Wisły [The empirical system of the characteristic rivers and streams floks in the Carpathian part of the Vistula basin]. Wiad. Inst. Met. i Gosp. Wod. 7 (27), 1-2, 31-40 (Engl. summ.).

RADECKI-PAWLIK A. 1995: Woda - v. 2.0 - A simple hydrological computer model to calculate the t-year flood. Hydrological processes in the catchment. Cracow University of Technology, Proceedings of the International Conference, Cracow, Poland.

RADECKI-PAWLIK A. 2000: Point bars development and sediment structure in the Skawica Creek in Polish Carpathians. International conference on transport and sedimentation of solid particles. Zesz. Nauk. AR we Wroctawiu 320, 113-120.

RADECKI-PAWLIK A., KLONOWSKA-OLEJNIK M., FLORENCKA N. 2002: Transport rumowiska, skład jakościowy osadów oraz chemizm wody potoku Młynne w Gorcach (Karpaty polskie) [The bedload transport, the sediments qualitative contents and the water chemistry in the Młynne Stream in Gorce (Polish Carpathians)]. Zeszyty Naukowe AR w Krakowie, Inżynieria Środowiska 22 (Engl. summ.).

RATOMSKI J. 2000: Podstawy projektowania zabudowy potoków górskich [The bases of mountains streams development]. PK, Kraków (in Polish).

Rozporządzenie Ministra Ochrony Środowiska, Zasobów Naturalnych i Leśnictwa z dnia 5 listopada 1991 r. w sprawie klasyfikacji wód oraz warunków, jakim powinny odpowiadać ścieki wprowadzane do wód lub do ziemi (Dz. U. z 1991 r., nr 116, poz. 503), (in Polish).

SZWALEC A., MUNDAŁA P., RADECKI-PAWLIK A., SZYMACHA A. 2007: Wpływ antropopresji na sukcesję roślinną i deponowanie pierwiastków śladowych w osadach dennych w rejonie budowli hydrotechnicznych na przykładzie wybranych potoków karpackich [The anthroporession influence on the plant succession and trace elements deposition in the bottom sediments nearby the hydrotechnical structures in the case od chosen Carpathains 
streams]. Infrastruktura i Ekologia Terenów Wiejskich 4, 153-166 (Engl. summ.).

TARNAWSKI M. 1996: Prognoza zamulania małego zbiornika wodnego położonego $\mathrm{w}$ zlewni karpackiej [The prognosis of small water reservoir in the Carpathian basin silting]. Masters thesis. Katedra Inżynierii Wodnej, AR w Krakowie. MS, Kraków (in Polish).

TOLKAMP H.H. 1980: Organism-substrate relationships in lowland streams. Centre for Agricultural Publishing and Documentation, Wageningen.

Wallingford University, 1996: The SandCalc1_1 software Wallingford, Great Britain.

WOŁOSZYN J., CZAMARA W., ELIASIEWICZ R., KRĘŻEL J. 1994: Regulacje rzek [The rivers regulation]. Wyd. AR we Wrockawiu, Wrocław (in Polish).

WYŻGA B., AMIROWICZ A., OGLĘCKI P., HAJDUKIEWICZ H., RADECKI-PAWLIK A., ZAWIEJSKA J., MIKUŚ P. 2014: Different response of fish and benthic invertebrate communities to constrained channel conditions in a mountains River: Case study of the Biała, Polish Carpathians. Limnologica 46, 58-69.

WYŻGA B., OGLĘCKI P., RADECKI-PAWLIK A., SKALSKI T., ZAWIEJSKA J. 2012: Hydromorphological complexity as a driver of the diversity of benthic invertebrate communities in the Czarny Dunajec River, Polish Carpathians. Hydrobiologia 696 (1), 29-46.

WYŻGA B., OGLĘCKI P., RADECKI-PAWLIK A., ZAWIEJSKA J. 2013: Zróżnicowanie zespołów makrozoobentosu jako odzwierciedlenie różnorodności siedliskowej w rzece górskiej poddanej zróżnicowanej przestrzennie antropopresji [Diversity of macroinvertebrate communities as the reflection of habitat heterogeneity in a mounatin river subjected to variable human impacts]. In: B. Wyżga (Ed.). Stan środowiska rzek południowej Polski - znaczenie środowiskowe, degradacja i możliwości rewitalizacji rzek wielonurtowych [Environmental significance, degradation and possibilities of restoration of Multi-thread rivers in sothern Poland]. Instytut Ochrony Przyrody PAN, Kraków, 115-142 (in Polish).

WYŻGA B., OGLĘCKI P., HAJDUKIEWICZ H., ZAWIEJSKA J., RADECKI-PAWLIK A., SKALSKI T., MIKUŚ P. 2013b: Interpretation of the invertebrate-based BMWP-PL index in a gravel-bed river - insight from the Polish Carpathians. Hydrobiologia 712, 71-88.

Streszczenie: Fauna makrobezkregowa na tle transportu rumowiska dennego oraz jakości wody w potoku Mtynne w Karpatach Polskich. W artykule poruszono temat składu osadów dennych oraz transportu zawiesiny w potoku górskim. Badania przeprowadzono na potoku Młynne w Gorcach. Płynie on częściowo korytem naturalnym, a częściowo uregulowanym poprzez kaskady. Zawiesina denna jest akumulowana w zbiorniku powyżej zapory i pod względem jakościowym różni się od tej gromadzącej się na kaskadach. Fauna bezkręgowa jest dobrym wskaźnikiem zmian hydromorfologicznych i ich wpływu na ekosystem. Bogactwa gatunkowe potoku Młynne jest nieco większe niż innych badanych cieków górskich i podgórskich, ale mniejsze $\mathrm{w}$ porównaniu $\mathrm{z}$ większymi rzekami. Liczba taksonów na odcinkach naturalnych jest ponaddwukrotnie większa niż na uregulowanych, przy większym udziale gatunków bardzo dużych wymaganiach siedliskowych i dużych wartościach wskaźnika BMWP-PL. W pracy poruszono problem przyjaznych środowisku rozwiązań technicznych przy różnych rodzajach działalności ludzkiej w dolinach rzek górskich i podgórskich, mogących korzystnie wpływać zarówno na dobro człowieka, jak różnorodność biologiczną i odporność ekosystemu na niekorzystne czynniki zewnętrzne.

Słowa kluczowe: strumień górski, transport materiału dennego, fauna bezkręgowa, zróżnicowanie siedliskowe, Karpaty, rzeka

\section{MS. received November 2015}

\section{Authors' addresses:}

Paweł Oglęcki

Katedra Kształtowania Środowiska

Wydział Budownictwa i Inżynierii Środowiska SGGW

ul. Nowoursynowska 159, 02-797 Warszawa

Poland

e-mail: pawel_oglecki@sggw.pl

Artur Radecki-Pawlik

Katedra Inżynierii Wodnej i Geotechniki

Wydział Inżynierii Środowiska i Geodezji

Uniwersytet Rolniczy w Krakowie

al. Mickiewicza 24-28, 30-059 Kraków, Poland e-mail rmradecki@cyf-kr.edu.pl 